\title{
Misunderstanding in the Interpretation of the Poem "Cinta Kepayang" in Gandrung by A. Mustofa Bisri
}

Abdul Wachid B.S.

Komunikasi Penyiaran Islam, Fakultas Dakwah dan Komunikasi, IAIN Purwokerto abdulwachidbs@gmail.com

\begin{tabular}{ll}
\hline \hline Informasi artikel & \\
\hline Sejarah artikel: & \\
Diterima: & 5 April 202I \\
Revisi: & 23 Oktober 202I \\
Dipublikasikan: & 30 Oktober 202I \\
\hline
\end{tabular}
\begin{abstract}
ABSTRAK
Mengungkapkan kesalahpahaman interpretasi tentang "cinta kepayang” dalam Gandrung karya A. Mustofa Bisri menjadi fokus riset ini. Ciri khas perpuisian A. Mutofa Bisri dalam Gandrung adalah puisinya begitu kaya dengan simbol yang memiliki keterkaitan dengan alam pikir mistisisme Islam (tasawuf). Alam pikir tersebut merupakan perpaduan antara pengalaman mistik dan pengalaman estetik. Penelitian ini menggunakan pendekatan kualitatif, guna menginterpretasikan dan menjelaskan objek penelitian, yaitu kesalahapahaman interpretasi tentang cinta kepayang. Jenis penelitian ini adalah library research dengan menumpulkan data primer dan sekunder terkait dengan buku puisi Gandrung karya A. Mustofa Bisri. Hasil penelitian ini mengungkapkan bahwa interpretasi "cinta" terrepresentasikan ke dalam dua gaya ungkap: pertama, memposisikan citra simbolik wanita sebagai tanda kehadiran dari keindaha Ilahiah, kedua, memposisikan citra simbolik wanita sebagai ekspresi paling sempurna dari peleburan cinta Ilahiah.
\end{abstract}

Kata kunci:

Interpretasi

Cinta Kepayang

Puisi

\section{Key word:}

Interpretation

Cinta Kepayang

Poetry

Gandrung

\begin{abstract}
This research aimed to reveal misunderstanding in the interpretation of the poem "Cinta Kepayang" in the poetry book Gandrung by A. Mustofa Bisri. The characteristic of A. Mustofa Bisri poems in Gandrung is that his poems are very rich in symbols related to the thought of Islamic mysticism (Sufism). The mind is a blend of mystical experience and aesthetic experience. This study uses a qualitative approach to interpretate the poem "Cinta Kepayang". It is library research by collecting primary and secondary data related to Gandrung by A. Mustofa Bisri. The results revealed that the interpretation of "Love" (Cinta) was represented in two styles; first, positioning the symbolic image of women as the presence of divine beauty, second, positioning the symbolic image of women as the most perfect expression of divine love fusion.
\end{abstract}

Copyright (O) 2018 Universitas Ahmad Dahlan. All Right Reserved

\section{Introduction}

In his study, Noor (2017) said that A. Mustofa Bisri's works, especially poetry, are not bound by tradition and conventions. Noor (2017) added that:

There is no A. Mustofa Bisri's single work, both short stories, and poetry, whose typography (lines, stanzas, words, sentences, paragraphs) is strange, eccentric, or looks different. In reading literature, the simplicity of typography facilitates the achievement of interpretation process.

Besides Noor, the aesthetics of A. Mustofa Bisri's poems are also the object of Malikah's study (2015). While Noor emphasizes the simplicity of A. Mustofa Bisri's expression, Malikah has a different opinion. Despite using daily language, the straightforward style is the aesthetic strength of A. Mustofa Bisri in his poems. The depth of spirituality is also a characteristic of A. Mustofa Bisri's poems. "Every A. Mustofa Bisri's poem contains symbols and meanings regarding Islamic mysticism (Sufism)," added Malikah (2015).

Religious literature (poem) becomes a reflection of the macro world (nature, humans, the transcendent world). "Religiosity prioritizes personal conscience, a personal attitude which is a mystery" (Al-Ma'ruf, 20I2).

That is, religiosity (Sufism) is positioned as wisdom in the world of literature. In Islamic treasures, religious literature refers to as Sufism literature (Faisal S, 2016). Purification of the soul is significant Sufism teaching. Therefore, Sufism's nuanced literature is a medium for reflection, contemplation, and reflection of the soul. The basic principle is love (Ardiani, 2018). 
Love in the world of Sufism (Sufi) is inclined to transcendence. It is because transcendence (the One) comes from inner vision (Ardiani, 20I8). Divine love is the basic term of Sufistic poetry. The idea of divine love according to Abdul Hadi W.M. (Saddhono, 2018) has a major place in the thought of the Sufis from the beginning of the Sufi development until today.

Characteristics of A. Mustofa Bisri's poems in the poetry book "Gandrung" are rich symbols related to the mind of Islamic mysticism (Sufism). The mind is a blend of mystical experience and aesthetic experience, illustrated by metaphysical imagery. "The poems generally speak of the issue of Divine love with the erotic beloved, relating to the drunkenness, wine, and also relating to mystic purity or nudity ('uryan)," as Abdul Hadi W.M. stated when He was identifying Hamzah Fansuri’s poetry (Hadi W.M, 200I).

The depiction of imagination in poems with the imagery of "Erotic Beloved," "drunkenness" and "mystic nudity" is also an important disclosure medium in A. Mustofa Bisri's poetry book. However, that is precisely what often makes misinterpretation among readers.

Why adoring (which in Javanese language and culture is called Gandrung) God in Sufis' poems was often misunderstood, as happened to A. Mustofa Bisri’s love poems (Gandrung)?

The depiction of imagination in poems with the imagery of "Erotic Beloved," "drunkenness," and "mystical nudity” in Sufic poems has caused misinterpretation and debate for a long time. At least Abdul Hadi W.M. through his book Tasawuf yang Tertindas (Hadi W.M., 200I) and Sangidu through his book Wachdatul Wujud (Sangidu, 2003), both of which are dissertations, have noted that misinterpretations also occurred in Hamzah Fansuri's work in Aceh at the end of the I6th century until the middle of the I7th century. Misinterpretations of the imagery "Erotic Beloved" occurred because the reader used literal interpretation. Therefore, it appears that Sufi's poems can mislead its readers.

The use of literal interpretation in A. Mustofa Bisri's love poems Gandrung will also lead to misinterpretations. The statements and descriptions colored by longing for "Erotic Beloved" always appear in love poems Gandrung. As in the following poem "Cinta Hingga" (Bisri, 2000).

\section{Cinta Hingga}

aku ingin menorehkan sejuta kecupan di tubuhmu yang panas hingga menimbulkan demam cinta yang membuatmu menggigil lalu kudekap kau hingga aku pun ikut menggigil dan tubuh kita menjadi satu semakin panas hingga akhirnya fana

......

I419

For readers, the phrase "...dan tubuh kita menjadi satu semakin panas..." literally means two bodies of lovers (a man and a woman) who are making love. However, if the phrase is read in its entirety with the subsequent phrase "...dan tubuh kita menjadi satu semakin panas hingga akhirnya fana ...," then the word "fana" demands the reader to give a hermeneutic interpretation of the poem thoroughly and completely. Thus, the physical form of poem (shurah), which describes a pair of lovers who are making love, will gain meaning (meaning of meaning $=$ ma'na al-ma'na) that "making love" is only the maximum signifier or the peak experience of human pleasure that signifies the intimacy (uns) of a person with his God. Of course, the phrase "...menjadi satu ... hingga akhirnya fana ..." is the depiction of the peak of oneness [of God].

In penetrating the deepest oneness (Tawhid), one must do it with a high spiritual discipline, purifying his self by denying anything other than God. Thus, one witnesses the unity of the One with his conscience, he experiences a "Fana," ie "the loss of the ego within a person because he has united and realized his union with God in life, such as acknowledging the oneness of God (Allah) as the All-Hearer and the All-Seeing (Al-Ataftazani, 1997). Since "Allah is the Light of the heavens and the earth" (Surat an-Nuur, 24:35), the depiction of the phrase "... menjadi satu...," The union of a human being with God (Khaliq), is also characterized by the life of an enlightened person because he has been illuminated by the light of God” ... until he finally has became Fana like the phrase ".fana menuju sukma-sukma kita yang lebih dahulu bersenyawa hingga utuhlah cahya kita, hingga utuhlah cahya kita. hingga utuhlah cahya kita, hingga ... "

The symbolic image of "Erotic Beloved" as in the poem "Cinta Hingga" also colored the Sufis' poems and the poems in "Gandrung" by A. Mustofa Bisri. The examples of erotic symbolic images in Sufi poems and their meanings have been discussed in chapter II. The erotic symbolic image in the poem "Gandrung” by A. Mustofa 
Bisri mostly describes how the eroticism of a person's longing for the Beloved. The image of "Beloved" has been described as "The erotic beloved" such as the following the poem "Gandrung" (Bisri, 2000).

\section{Gandrung}

selama ini

aku telah menghabiskan umurku untuk entah apa. di manakah kau ketika itu, o, kekasihku? mengapa kau tunggu hingga aku lelah tak sanggup lagi

lebih keras mengetuk pintumu menanggung maha cintamu? benarkah kau datang kepadaku o, rinduku, benarkah?

1998

The poem "Gandrung" describes how two lovers miss each other and want to meet. The yearner (poet) mentioned erotically the existence of his Beloved with: "selama ini/ aku telah menghabiskan umurku/ untuk entah apa/ di manakah kau ketika itu, o kekasihku?" This intimacy is like the intimacy of two human beings (a man and a woman) who are dominated by longing.

However, space and time separate them because they are blocked by the "door" (pintu). To enter the door, the lover (poet) must knock the door harder as the phrase "lebih keras mengetuk pintumu." Because of his longing, the lover (poet) seemed to doubt the presence of the "Beloved" as in the questions in the poem: "benarkah/kau datang padaku/ o, rinduku,/ benarkahy" Meanwhile, his longing is caused by enormous love as the phrase "menanggung maha cintamu."

The word "door" (pintu) which has been mentioned in the poem "Gandrung" is a keyword (matrix) that opens the door of meaning relates to a romantic relationship. The word "door" (pintu) in the poem is not a door in the literal sense, but a door in deep inner sense or meaning so that the lover (poet) feels unable to knock on the door as in the phrase "...aku lelah/tak sanggup lagi/ lebih keras mengetuk pintumu/..." Whether the door will open or not depends on "lover's knock", whether the Beloved who is behind the "door" hears the knock or not. However, the word "door" also makes the meaning of the poem increasingly clear that the relationship of "You" (kau) and "I" (aku) is not the romance between a man and a woman, but a man who experiences inner love and endures enormous love, such as the phrase "menanggung maha cintamu," for his God, Allah.

The word "door" (pintu) which has been mentioned in the poem "Gandrung" has the same meaning with the meaning that is in the Sufis' poems, the symbol of forgiveness. The forgiveness is obtained through repentance, which is the first door for the Sufis to enter the further spiritual levels. The forgiveness gained through repentance is given by Allah because He is The All-Compassionate (al-Rahman) and The All-Merciful (al-Rahim) as the hadith of the Prophet concerning the throne of Allah (al-arsy): "Verily, My Mercy prevailed over My Wrath" (inna rahmati sabaqat ghadhabi).

The symbolic image of "Erotic Beloved" as the love poem "Gandrung" by A. Mustofa Bisri colores the depiction of human longing for his Lord in another poem in the love poetry book "Gandrung." Through fortyfour titles of poems, there are thirty titles of poems that use the symbolic image of "Erotic Beloved," two titles of poems have been already discussed. The thirtytitles of poem are: (I) "Sajak Cinta", (2) "Bila Senja", (3) "Al'isyq", (4) “Cinta Hingga", (5) "Tembang”, (6) "Engkau Kulepas", (7) "Malam Itu”, (8) "Gandrung”, (9) "Sajak Putih Buat Kekasih", (I0) "Seporsi Cinta", (II) "Selly", (I2) "Hanien", (I3) "Senyum Subuh", (I4) "Pusaran”, (I5) "Tantangan", (I6) "Halte", (I7) "Dalam Kereta", (I8) "Ilhaah I", (I9) "Ilhaah 2", (20) "Cintaku", (2I) "Tak Cukup", (22) "Cintaku yang Perkasa”, (23) "Selembar Daun", (24) "Perkenankanlah Aku Mencintamu”, (25) "Wakhsyah", (26) "Syauq", (27) "Insijam", (28) "Setiap Kali Berkelebat", (29) "Persaksian", and (30) "Liqaa". 
Because the use of "Erotic Beloved" as the symbolic image is very dominant, A. Mustofa Bisri's choice of the poem "Gandrung" as the title of his poetry book is the right decision because all his poems depict and explain the variants of human longing for God. In fact, the longing has reached to the level of love (adore), which is infatuated by the unstoppable love.

\section{Method}

It is library research, exploring the object through various library information, especially books and scientific journals. In this study, the researcher obtained the meaning of love from the book of poetry Gandrung by A. Mustofa Bisri. Researchers used a qualitative approach with descriptive explanations as its characteristics (Mustika Zed, 2008).

Researchers use documentation as a data search method by reading, analyzing, and parsing information about the object. In addition to A. Mustofa Bisri's works, the author also uses some data on Sufism which discusses the issue of love (mahabbah). Hamzah Fansuri is a Sufi-poet whose poems become secondary data because Hamzah Fansuri's poems have similarities with A. Mustofa Bisri's poems, namely the dimensions of Sufism, love (mahabbah, isyq).

The researcher focuses on positioning and parsing data using words and sentences in data analysis(Faisal, 20I0). The aim is to identify meaning and theory (Ratna, 20I I).

\section{Result and Discussion}

\section{The Description of Love for Allah in Two Styles}

Forty-four titles of poems contained in the love poetry book "Gandrung" show that the various longing depicted in the love poetry book "Gandrung" by A. Mustofa Bisri does not explain to us why the form of longing in the poems varies? The various longing likes the Sufi-poet Rabi'ah al-Adawiyah which gives a different description as well as complement each other about two forms of love to God, namely "Love because of myself and love for Yourself (Allah)" (Asfari MS dan Soekatno Cr, 2002).

Aku mencintai-Mu dengan dua cinta

Cinta karena diriku dan cinta karena diri-Mu

Cinta karena diriku

Adalah keadaan senantiasa mengingat-Mu

Cinta karena diri-Mu

Through the reading of A. Mustofa Bisri's poems containing Sufism, the longing illustrated gives us suggestions that human's longing for God is a human's effort to know and love God through His creation. This is expressed by showing the beauty of nature as His creation, including the beauty of human, especially in the woman. The view of A. Mustofa Bisri's Sufism is not expressed verbally, but its meaning can be reconstructed through all of his poems in the love poetry book "Gandrung". In his book Fusus al-Hikam, Ibn 'Arabi explained that witnessing the Real in women is the most complete representation, as the locus of acceptance.

Miftahul Ula (2016) interprets Syair Perahu by Hamzah Fansuri that humans live on earth like a boat sailing in the middle of an ocean. This voyage will lead to eternity (hereafter). A. Mustofa Bisri and Hamzah Fansuri have the same locus in expressing their longing for the Most Beautiful. While Hamzah Fansuri uses the symbol of a boat, A. Mustofa Bisri uses the symbol of women as an image to express his longing for the Beautiful.

The aesthetic strength of A. Mustofa Bisri's poetry, as Hamzah Fansuri, lies in its imagery which has implications for certain atmospheres and events (Burhanudin, 2017). In A. Mustofa Bisri's poems, Sufistic imagery becomes principal and contemplative poetic and closely related to dynamic sensory perception. A. Mustofa Bisri's view concerning the longing for God and the love of God, "his witness to the Real in woman," is expressed in his poems through the following two styles.

\section{The Symbolic Image of Woman as The Presence of Divine Beauty}

The first style is in the poem "Al'isyq": memposisikan citra simbolik wanita sebagai tanda kehadiran dari keindahan Ilahiah, yang dalam sajak disebutnya sebagai "tanda-tanda sayang"(Bisri, 2000). However, in this style, the woman is still perceived as an entity that disturbs worship as in the phrase "masih mengganggu perjalanan ibadahku" because the entity admired is still in the perspective of literal beauty. However, the symbolic image of the woman becomes part of "signal from you (isyarat darimu)". Therefore, by interpreting the symbolic image of woman as Allah's most perfect creation, Allah accepts the poet's love as in the phrase "cintaku kau terima" (the 
poem "Selembar Daun," 2000: 58). The symbolic image of the woman is still described as the "signs of affection" from Allah, but not yet a fusion of love. Therefore, first-person usage (aku-lirik) still indicates the poet's worries as in the phrase "Apakah cinta kita tak utuh/Mengapa kita tak juga bersetubuh." (Bisri, 2000).

There are the five titles of poems from the thirty titles of poems that use the symbolic image of "Erotic Beloved" with the first style: (I) "Al'isyq", (2) "Tembang", (3) "Selly", (4) "Senyum Subuh", dan (5) sajak "Pusaran". Satu di antaranya adalah sajak "Al'isyq" (Bisri, 2000) yang dikutip selengkapnya berikut ini.

\author{
Al'isyq \\ Semua saksi \\ Tak mencatat kencan-kencan kita \\ Juga tanda sayang \\ Yang kutebar di sekujur dirimu \\ Sirna entah kemana. \\ Sementara hingga kini \\ Bau lipatan-lipatan tubuhmu \\ Masih mengganggu perjalanan \\ Ibadahku. \\ Apakah cinta kita tak utuh \\ Mengapa kita tak juga bersetubuh?
}

$1399 / 1415$

The phrase "Semua saksi/Tak mencatat kencan-kencan kita/Juga tanda sayang/Yang kutebar di sekujur dirimu/Sirna entah kemana./.." is the imagination concerning the level of awareness that all the pleasures in this world are temporary (not eternal). Therefore, the poem asks the question "Is our love incomplete? Why do not we also have sexual intercourse?" as the phrase "Apakah cinta kita tak lengkap/Mengapa kita tak juga bersetubuh?"

However, the poem does not mean that A. Mustofa Bisri was suggesting sexual activity. As a way of reaching the level of spiritual experience, A. Mustofa Bisri only suggested and illustrated that human perfection can only be attained by the lovers of God (awliya) and the Prophets. Therefore, "the witness to the Real in the woman" is impossible for most people because, as Ibn 'Arabi said, "Most people are animal-humans (al-insan al-hayawan)." Kasyani said (Murata, 1996) that through marriage, "the witness to the Real in sexual intercourse is the most perfect."

In the poem "Tembang" (Bisri, 2000). A. Mustofa Bisri also displayed the imagination concerning the level of awareness:

\title{
Tembang
}

\author{
seperti bermimpi \\ kudengar gumam tembang di sampingku \\ seorang wanita bagai puteri dari dongeng seribu satu \\ malam \\ asyik sendiri bermain-main sendiri \\ o, inginnya aku mengawaninya lena \\ dalam dunia kesendiriannya yang penuh pesona itu \\ diam-diam kucuri-tatap wajahnya yang tersenyum \\ mencari-cari sesuatu yang mungkin sengaja \\ disembunyikan \\ I0.7.1998
}

For the sake of hearing the voice of the soul, like the phrase "mencuri dengar tembang jiwamu," the existence of the woman is in marriage and also on the path to the noble ideals such as the phrase in the poem 
"Selly," “... yang melangkah mantap/di jalan Tuhan/menuju cita-cita mulia/..." (Bisri, 2000). Why is that? It is so that a person does not lose control and can control himself as in the phrase in the poem "Pusaran" (Bisri, 2000) "//Aku nyaris tersedot pusaran matanya/ Ke titik tak terkendali/ Tanpa janji kembali."

Meanwhile, the woman who walks with certainty in the way of God, as the phrase "... yang melangkah mantap/di jalan Tuhan/...", does not only exist in her existence but exist in her absence. Such woman moves from the outward beauty to the inner beauty. Therefore, such a woman reigns in the heart, a place of love and divine truth as the phrase: "Kini dalam sepi subuhku sendiri/Aku melihat senyum seperti senyummu/ Berkelebat menghentikan langkahku/ Hatiku pun memanggilmu" (The poem "Senyum Subuh") (Bisri, 2000).

The phrase "...Berkelebat menghentikan langkahku/ Hatiku pun memanggilmu" shows a heart that constantly remembers (dhikr) Allah. Thus, the heart perceives and positions woman as symbolic images, as the most perfect expression concerning the fusion of Divine love.

\section{The Symbolic Image of Woman as the Expression Concerning the Fusion of Divine Love}

The second style is to position the symbolic image of woman as the most perfect expression concerning the fusion of Divine love. In such poems, the position of woman is no longer as an entity that disturbs worship as in the phrase "... mengganggu perjalanan ibadahku" (the poem "Al'isyq") (Bisri, 2000). On the contrary, in the culmination of a Sufi's intimacy with Allah (uns), the symbolic image of woman as literal beauty, in this context, obtains inner meaning. In fact, in many poems, the fusion of Sufi's love for God is portrayed as an erotic fusion of a man with a woman.

The style was used widely in A. Mustofa Bisri's poems. From the thirty titles of poems using the symbolic image of Erotic Beloved, there are five poems that use the first style and twenty-five poems that use the second style, which positions the symbolic image of woman as the most perfect expression concerning the fusion of Divine love.

As for the twenty-five poems that use the second style: (I) "Sajak Cinta", (2) "Bila Senja", (3) "Cinta Hingga", (4) "Engkau Kulepas", (5) "Malam Itu”, (6) "Gandrung", (7) "Sajak Putih Buat Kekasih", (8) "Seporsi Cinta", (9) "Hanien", (I0) "Tantangan", (II) "Halte", (I2) "Dalam Kereta”, (I3) "Ilhaah I", (I4) "Ilhaah 2", (I5) "Cintaku”, (I6) "Tak Cukup", (I7) "Cintaku yang Perkasa”, (I8) "Selembar Daun", (19) "Perkenankanlah Aku Mencintamu", (20) "Wakhsyah", (2I) "Syauq", (22) "Insijam", (23) "Setiap Kali Berkelebat", (24) "Persaksian", and (25) "Liqaa". The twenty-five poems will be discussed in another article.

"Positioning the symbolic image of woman as the most perfect expression concerning the fusion of Divine love" will be interpreted not only as a style of expressing poems because the researcher has described it in the subsection "Puitika dalam Gandrung karya A. Mustofa Bisri : Tamsil Metafisik dalam Sajak yang Tak Memperindah Kata-kata" and "Kesalahpahaman Interpretasi tentang Cinta Kepayang."

Hermeneutical interpretation is done by understanding the symbols and "excavating" their meaning carefully in poems (Faiz, 2002) for the sake of philosophical steps, that are thinking by using symbols as a point of departure (Ricoeur, 2003). Then, the hermeneutic interpretation is used simultaneously (Sumaryono, 1999) because there is no understanding of symbols without knowing the usage of symbols and the meaning of symbols; and there is no understanding and interpretation of symbols without an interest to reconstruct the philosophy of life embodied in these symbols. There is no interpretation without a simultaneous relation between text, context, and contextualization.

\section{Conclusion}

The research revealed that the interpretation of "love" had two styles: first, positioning the symbolic image of woman as a sign concerning the presence of Divine beauty; second, positioning the symbolic image of woman as the most perfect expression concerning the fusion of Divine love. The first style showed that woman is still perceived as "an entity that disturbs worship" because the woman was still admired by the perspective of literal beauty. While the second style showed that woman was not perceived as "an entity that disturbs worship." On the contrary, in the culmination of a Sufi's intimacy or closeness with Allah (uns), the symbolic image of woman as a beauty that was originally interpreted literally, in this context it is interpreted hermeneutically.

\section{Acknowledgment}

The author would like to thank all parties involved in the process of completing this research. Furthermore, he also dedicates his gratitude and high respect to the editorial team of Bahastra who has published this article. 


\section{REFERENCE}

Al-Ataftazani, A. al-W. al-G. (1997). Sufi dari Zaman ke Zaman. Bandung: Penerbit Pustaka.

Al-Ma'ruf, A. I. (2012). Dimensi Sufistik dalam Stilistika Puisi "Tuhan, Kita Begitu Dekat” Karya Abdul Hadi

W.M. Tsaqafa: Jurnal Seni Dan Budaya Islam, I(I), 106.

Ardiani, D. (2018). Maqam-maqam Dalam Tasawuf, Relevansinya Dengan Keilmuan dan Etos Kerja. Jurnal Suhuf, 30(2), I68-I77.

Asfari MS dan Otto Soekatno Cr. (2002). Mahabbah Cinta Rabiah al-Adawiyah. Yogyakarta: Bentang.

Bisri, A. M. (2000). Sajak-sajak Cinta Gandrung. Rembang: Al-Ibris.

Burhanudin, M. (2017). Nilai Humanisme Religius Syiir Pesantren". Jurnal Sastra Indonesia,. Jurnal Sastra Indonesia, 6(I), 35-42.

Faisal, S. (2010). Format-format Penelitian Sosial. Jakarta: Raja Grafindo Persada.

Faisal S, B. (2016). Dimensi Tasawuf Dalam Puisi Acep Zamzam Noor. Jurnal Al-Tsaqafa, I3(I), I I-I9.

Faiz, F. (2002). Hermeneutika al-Qur'an. Yogyakarta: Qolam.

Hadi W.M., A. (200I). Tasawuf yang Tertindas. Jakarta: Paramadina.

Hadi W.M, A. (200I). Tasawuf yang Tertindas. Jakarta: Paramadina.

Malikah, N. (2015). Nilai-nilai Sufistik Puisi "Mencari Bening Mata Air” Dalam Perspektif Dakwah. Jurnal AnNida, 72), I06-I22.

Murata, S. (1996). The Tao of Islam. Bandung: Mizan.

Mustika Zed. (2008). Metode Penelitian Kepustakaan. Jakarta: Yayasan Obor Indonesia.

Noor, R. (2017). Kebersahajaan Ekspresi dan Mana Karya Sastra Mustofa Bisri. Nusa, I2(3), 12-I9.

Ratna, N. K. (20I I). Teori, Metode, dan Teknik Penelitian Sastra: dari Strukturalisme hingga Poststrukturalisme Perspektif Wacana Naratif. Yogyakarta: Pustaka Pelajar.

Ricoeur, P. (2003). Filsafat Wacana: Membelah Makna dalam Anatomi Bahasa (The Interpretation Theory: Discourse and the Surplus of Meaning). Yogyakarta: Ircisod.

Saddhono, K. dan H. (2018). Nuansa dan Simbol Sufistik Puisi-Puisi Karya Ahmad Mustofa Bisri. Teosofi: Jurnal Tasawuf Dan Pemikiran Islam, 8(I), 3I-6I.

Sangidu. (2003). Wachdatul Wujud: Polemik Pemikiran Sufistik antara Hamzah Fansuri dan Syamsuddin asSamatrani. Yogyakarta: Gama Media.

Sumaryono, E. (1999). Hermeneutik, Sebuah Metode Filsafat. Yogyakarta: Kanisius.

Ula, M. (2016). Simbolisme Bahasa Sufi (Kajian Hermeneutika terhadap Puisi Hamzah Fansuri). Jurnal Religia, IP(2), 26-4I. 